\title{
Studying with Bream
}

\author{
Alice Artzt \\ United States of America
}

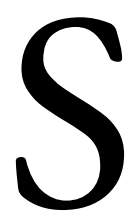

ince beginning to study classical guitar at around age 13, I listened to every guitarist, went to every guitar concert, and got every guitar record I could find, including Segovia, Presti and Lagoya, and of course Bream. I was a fanatic. Bream was a particular favorite since much of the music he played was what I especially loved. My teacher in New York was Alexander Bellow, who taught more or less a Segovia oriented technique. After about 6 years of very intense studying, practicing religiously 6 hours a day, I had learned about all I could from Mr. Bellow. Then I heard Ida Presti and Alexandre Lagoya perform in NY, and found out that they would be giving a master class in Canada that summer. So I was lucky enough to be able to go to that, which enabled me to develop a much better more stable technique, as well as meet several wonderful young guitarists who became good friends. Several of us had decided to go to France the following summer to continue our studies with Ida Presti, and when we found out that Bream would be giving a class in England, a few weeks earlier, that meant we could go to that class as well. It was to be held at a "stately home" called Phillips House (a suburb of Stonehenge, my father called it). I remember I had to audition for that class with Bream in New York, and the only thing I still remember was that, after I had played, he commented on the piece, and did a little demonstration of one place he thought should have been different, and in doing that demonstration, he just stood beside me on one leg, and balanced the guitar held up on his other knee, and played - I thought quite impressively - in that totally impossible unstable position.

So I went to Phillips House with my Presti/Lagoya student friends, and met another dozen or more students there - all of us working hard and determined to make careers. We each got about an hour's lesson once a week, and then of course listened to everyone else's lessons, as well as practiced a 
lot. I remember a TV station - perhaps the BBC - came out to do a program on the class, and they wanted to have film of us sitting all around the estate's gardens and shrubbery practicing (which we never actually would have done - we worked in our rooms, where we could concentrate, with our music on the desks, of course). So we dutifully draped ourselves around outside so they could film us. Bream also wanted us to play a game of cricket, which he adored, for the TV people to film. But many of us were Americans or from various other countries - Japan, Brasil, France, Israel, etc., and we didn't know how to play cricket. But we tried, and I suppose they got some usable footage. They did also record some footage of the actual classes, and I remember in one case I was playing and Bream grabbed his guitar and started playing the same piece along with me - and then he started to play faster and faster and I had to manage to keep accelerating to keep up with him - had to uphold the honor of the USA and not give up and drop out in the middle of the piece.

Bream generally didn't tell us much about actual technique. He seemed to be of the opinion that it was a personal choice, and also that most of us pretty much knew what we wanted to do. He did work on suggesting fingerings, and did a lot of encouragement, and stylistic or musical suggestions. He also played for us quite a lot, and that was a great inspiration. He had already recorded the Britten Nocturnal, and I had just got the music a few weeks before, and so I started working on that to play for him. Other students told me that Bream would be upset that I would dare play it after knowing it for such a short time, since he had not performed it until he had been working on it for a year. But actually he never complained about that at all, and I am very glad I did play it for him, as he told me some little details about what Britten had told him about his inspiration for that piece - for instance, that one passage in the piece was supposed to depict mist rising from a little pond the middle of the forest - which were good things to know.

The class was in June/July, and Bream's birthday fell during the class, so he had a birthday party, to which we were all invited. I remember that getting to his house from the class was tricky since we only had a couple of cars. So we had people sitting on each other's laps in all but the driver's seat. I think we got at least 9 people into the VW station wagon my friends had there. Bream loved Django Reinhardt and had records of his, so I got to hear that music for the first time. There was also quite a lot of booze offered, which didn't attract me at all, but I do remember that, fairly late into the evening, we noticed that one South American student seemed to be missing. Someone went out to look around for him, and eventually came back saying he found him - he was out under a bush in the 
garden being sick, and that he said to tell us "he loves everybody and thinks he is going to die".

After that my friends and I managed to get 5 of us -3 guitarists plus one wife and a small baby, 3 guitars, all our baggage, plus several big packages of diapers (that were reputed to be cheaper in England than in France) into, or onto the roof rack of, the aforementioned VW station wagon, and we drove down to Nice to the Presti/Lagoya class there. But that was another wonderful adventure...

\section{ABOUT THE AUTHOR}

Ms. Artzt, whom Guitar international Magazine has called “America's best player”, made her solo concert debut in London in 1969. Since then critics in Europe, Asia, Africa, Australia, and the Americas have unanimously acclaimed her performances as a soloist, in concertos with orchestra, and in chamber music groups. She studied guitar with Julian Bream, Ida Presti and Alexandre Lagoya, and composition with Darius Milhaud at Aspen Colorado and at Columbia University where she got a degree in musicology. Alice Artzt has made 13 solo records (LP or CD), and has written two books on guitar technique (available on Amazon) as well as many articles on music in various magazines. She has taught for the past 50 years in private lessons and in master classes all over the world. (Several of her instructional videos are on YouTube.) She has appeared on TV and radio throughout the world, and has been on the juries of many international guitar competitions (CAG, GFA, Toronto, Segovia NYU, Rodrigo, and Alessandria).E-mail: guitartzt@aol.com 